\title{
华北地区落叶松林的分布、群落结构和物种多样性
}

\author{
方文静 $^{1}$ 蔡 琼 ${ }^{1}$ 朱江玲 ${ }^{1}$ 吉成均 ${ }^{1}$ 岳 明 ${ }^{2}$ 郭卫华 ${ }^{3}{\text { 张 峰 }{ }^{4} \text { 高贤明 }}^{5}$ \\ 唐志尧 ${ }^{1}$ 方精云 ${ }^{*}$
}

${ }^{1}$ 北京大学城市与环境学院, 北京大学生态研究中心, 地表过程分析与模拟教育部重点实验室, 北京 $100871 ;{ }^{2}$ 西北大学西部资源生物与现代生物技术 教育部重点实验室, 西安 710069; ${ }^{3}$ 山东大学生命科学学院生态学与生物多样性研究所, 山东青岛 266237; ${ }^{4}$ 山西大学黄土高原研究所, 太原 030006 ; ${ }^{5}$ 中国科学院植物研究所植被与环境变化国家重点实验室, 北京 100093

\begin{abstract}
摘 要 华北落叶松(Larix principis-rupprechtii)林、日本落叶松(L. kaempferi)林及太白红杉(L. chinensis)林是华北地区常见的 3 种落叶松林类型，其中日本落叶松林为人工林，华北落叶松林既有天然分布又有人工种植，太白红杉林则主要是天然林。该 研究基于野外调查数据, 对这3种落叶松林的分布、物种组成、群落结构、物种多样性及其与环境间的关系进行了分析。研 究发现, 3 种落叶松林的分布受年平均气温的影响较大, 随着年平均气温的增加, 落叶松林的天然分布减少而人工种植的分布 增加。3种森林中落叶松的林分径级及树高均为右偏分布, 说明 3 种落叶松林均处于相对稳定的演替阶段。3种落叶松林均拥 有较高的物种丰富度且差异显著, 其中太白红杉林的物种丰富度最大 $(39.3 \pm 17.9)$, 而华北落叶松林的物种丰富度最小 (人工 林 $27.2 \pm 17.7$, 天然林 $27.5 \pm 13.8$ )。除最大树高与经度的关系不显著以外, 落叶松林的最大胸径和最大树高及物种丰富度均随 经纬度的增加而显著降低, 随着年降水量的增加而显著增加。此外, 年平均气温对落叶松林的总物种丰富度影响不大, 但是 对其群落结构影响显著。随着年平均气温的升高, 落叶松林的最大胸径显著降低而最大树高却显著增加。落叶松天然林和落 叶松人工林物种多样性的地理分布格局及与气候因子间的关系与落叶松林总体的基本一致，但群落结构的格局不尽相同：随 着经纬度的增加, 落叶松人工林的最大树高增加而天然林的最大树高减小; 落叶松天然林的最大胸径和最大树高分别随年平 均气温的升高和年降水量的增加而减小, 而落叶松人工林的最大胸径和最大树高分别随年平均气温的升高和年降水量的增 加而增大。
\end{abstract}

关键词 落叶松林; 华北落叶松; 日本落叶松; 太白红杉; 群落结构; 物种组成; 物种多样性

方文静, 蔡琼, 朱江玲, 吉成均, 岳明, 郭卫华, 张峰, 高贤明, 唐志尧, 方精云 (2019). 华北地区落叶松林的分布、群落结构和物种多样性. 植物生态 学报, 43, 742-752. DOI: 10.17521/cjpe.2018.0244

\section{Distribution, community structures and species diversity of larch forests in North China}

FANG Wen-Jing ${ }^{1}$, CAI Qiong ${ }^{1}$, ZHU Jiang-Ling ${ }^{1}$, JI Cheng-Jun ${ }^{1}$, YUE Ming ${ }^{2}$, GUO Wei-Hua ${ }^{3}$, ZHANG Feng $^{4}$, GAO Xian-Ming $^{5}$, TANG Zhi-Yao ${ }^{1}$, and FANG Jing-Yun ${ }^{1 *}$

${ }^{1}$ Institute of Ecology, College of Urban and Environmental Sciences, Laboratory for Earth Surface Processes of the Ministry of Education, Peking University, Beijing 100871, China; ${ }^{2}$ Key Laboratory of Resource Biology and Biotechnology in Western China, Ministry of Education, Northwest University, Xi'an 710069, China; ${ }^{3}$ Institute of Ecology and Biodiversity, School of Life Sciences, Shandong University, Qingdao, Shandong 266237, China; ${ }^{4}$ Institute of Loess Plateau, Shanxi University, Taiyuan 030006, China; and ${ }^{5}$ State Key Laboratory of Vegetation and Environmental Change, Institute of Botany, Chinese Academy of Sciences, Beijing 100093, China

\footnotetext{
Abstract

Aims Larch forests are important for timber harvesting and water-soil conservation in North China. To explore the distribution, community structure and species diversity of larch forests is important for the vegetation conservation and sustainable utilization in North China.

Methods We collected species composition and local environment for 215 forest plots dominated by three common larch species, namely, Larix principis-rupprechtii, L. kaempferi and L. chinensis, in North China during 2000-2017. Among these types, L. kaempferi forests are planted, while L. chinensis forests are almost natural, and most of L. principis-rupprechtii forests are natural. Based these data, we used the canonical correspondence analysis (CCA) to explore the relationship between species composition and environment. We also explored the pattern of community structure and species diversity of these three forests in relation to environmental factors.

收稿日期Received: 2018-10-03 接受日期Accepted: 2018-12-24

基金项目：国家科技基础性工作专项(2011FY110300和2015FY210200)。Supported by the National Basic Work of Science and Technology of China (2011FY110300 and 2015FY210200).

* 通信作者Corresponding author (jyfang@urban.pku.edu.cn)
} 
Important findings Mean annual air temperature (MAT) was the most important factor for the distribution of these larch forests. The proportion of natural forest decreased, while that of planted forest increased, with MAT. Diameter at breast height $(D B H)$ and height distribution of three larch forests were right-skewed, indicating that all of these larch forests are at relatively stable successional stage. Species richness differ remarkably among different larch forests, which was highest in the L. chinensis forests $(39.3 \pm 17.9)$, followed by the L. kaempferi forests $(37.4 \pm 22.4)$, and lowest in the L. principis-rupprechtii forests (planted forests $27.2 \pm 17.7$, natural forests $27.5 \pm 13.8$ ). Species richness, the maximum $D B H$ and the maximum height decreased with latitudes and longitudes. Species richness, the maximum $D B H$ and the maximum height increased with annual precipitation. However, species richness showed no significant trend, and the maximum height increased, while the maximum $D B H$ decreased, with MAT. The patterns of species richness along geographical and climatic gradients were consistent between the planted, the natural and the overall (including both planted and natural) larch forests. However, the patterns of community structure differed remarkably among planted, natural and overall larch forests. The maximum height of planted forests increased, while that of natural forests decreased, with latitude and longitude. The maximum $D B H$ and height of natural forests decreased, while those of planted forests increased, with MAT and annual precipitation, respectively.

Key words larch forest; Larix principis-rupprechtii; Larix kaempferi; Larix chinensis; community structure; species composition; species diversity

Fang WJ, Cai Q, Zhu JL, Ji CJ, Yue M, Guo WH, Zhang F, Gao XM, Tang ZY, Fang JY (2019). Distribution, community structures and species diversity of larch forests in North China. Chinese Journal of Plant Ecology, 43, 742-752. DOI: 10.17521/cjpe.2018.0244

落叶松属(Larix)植物是中国北方广泛分布的寒 温性针叶林的建群种, 也是重要的用材树种(吴征 镒, 1980; 李楠, 1995; 刘增力等, 2002)。在我国华北 地区，落叶松属植物是很多山地的林线物种，如太 白山的林线物种为太白红杉(Larix chinensis)(段仁 燕等, 2010), 五台山、关帝山及小五台山的林线物 种为华北落叶松(L. principis-rupprechtii)(Liu et al., 2002), 这些落叶松对维护高海拔地区的生态环境 有重要意义。目前中国华北地区主要分布有3种落叶 松：华北落叶松、日本落叶松(L. kaempferi)及太白红 杉(郑万均, 1983)。其中, 华北落叶松及太白红杉是 中国特有种，日本落叶松为华北地区广泛栽培种 (郑万均和傅立国, 1978)。这3种落叶松是华北地区 落叶松林的优势种。其中, 日本落叶松林为人工林; 而华北落叶松林虽然在华北地区有天然分布, 但是 由于其分布的海拔较低, 受人为干扰严重, 因而目 前纯原始林较少, 大部分是受干扰的次生林或者栽 培的人工林(刘濂, 1996); 相较而言, 太白红杉林虽 仅分布于我国秦岭山地, 但其分布海拔较高, 受人 为干扰影响较小, 且其适应性极强, 在土层贫㾑气 候寒冷的条件下也能适应, 为我国秦岭山区森林上 限植被, 目前主要是原始林(雷明德, 1999; 应俊生 和陈梦玲, 2011)。

落叶松林作为我国华北地区重要的用材林及水 土涵养林, 探讨其整体的分布规律及其群落结构和
物种多样性的基础研究十分有必要。前人关于华北 地区落叶松林的研究较为分散, 对于华北落叶松和 日本落叶松林多集中在研究林分结构、林木生长和 物种多样性(韩艳英, 2006; 马友平, 2007; 武秀娟等; 2010; 孔令伟等, 2014), 生物量、生产力及碳密度 (宿以明，1995; 赵体顺等，1999; 罗云建等，2009; 陈东升等, 2016; 纪文婧等, 2016; 马丰丰等, 2016) 以及空间分布格局(间海冰等, 2010; 张钦弟等, 2010)等方面。而对太白红杉林的研究主要集中在群 落分布及空间格局(郭华, 2004; 许林军等, 2005b), 群落结构特征及物种多样性(阎桂琴等, 2001; 许林 军等, 2005a)以及群落更新(涂云博, 2008)等方面。而 立足于区域性的，对中国华北地区落叶松林整体的 研究鲜有报道。

\section{1 材料和方法}

\section{1 研究区域概况}

研究区域涵盖了华北落叶松和太白红杉的天然 分布区域，包括了我国北方的大部分区域，从东向 西分别是山东、河北、北京、内蒙古、河南、山西、 陕西、宁夏(表1; 图1)。三种落叶松林的森林样方如 下：日本落叶松林 36 个样方均为人工林; 太白红杉 林 29 个样方均为天然林; 华北落叶松林 150 个样方 中 66 个样方为人工林, 84 个样方为天然林(表1)。 
表1 华北地区3种落叶松林的调查区域

Table 1 Investigation area of three larch forests in North China

\begin{tabular}{|c|c|c|c|}
\hline 落叶松林类型 Larch forest type & 起源类型 Origination & 样方数量 No. of plots & 主要调查地点 Main sites \\
\hline \multirow[t]{5}{*}{$\begin{array}{l}\text { 华北落叶松林 } \\
\text { Larix principis-rupprechtii forest }\end{array}$} & 人工林 Planted forest & 66 & $\begin{array}{l}\text { 山东: 泰山等 } \\
\text { Shandong: Mt. Taishan etc. }\end{array}$ \\
\hline & 天然林 Natural forest & 84 & $\begin{array}{l}\text { 河北: 雾灵山、小五台山等 } \\
\text { Hebei: Mt. Wuling, Mt. Xiaowutai etc. }\end{array}$ \\
\hline & & & $\begin{array}{l}\text { 内蒙古: 大青山 } \\
\text { Nei Mongol: Mt. Daqing }\end{array}$ \\
\hline & & & $\begin{array}{l}\text { 山西: 太行山、中条山等 } \\
\text { Shanxi: Mt. Taihang, Mt. Zhongtiao etc. }\end{array}$ \\
\hline & & & $\begin{array}{l}\text { 宁夏: 六盘山 } \\
\text { Ningxia: Mt. Liupan }\end{array}$ \\
\hline \multirow[t]{2}{*}{ 日本落叶松林 L. kaempferi forest } & 人工林 Planted forest & 36 & $\begin{array}{l}\text { 山东: 崂山、昆嵛山等 } \\
\text { Shandong: Mt. Laoshan, Mt. Kunyu etc. }\end{array}$ \\
\hline & & & $\begin{array}{l}\text { 河南: 玉皇山、龙峪湾林场 } \\
\text { Henan: Mt. Yuhuang, Longyuwan Forest Farm }\end{array}$ \\
\hline 太白红杉林 L. chinensis forest & 天然林 Natural forest & 29 & $\begin{array}{l}\text { 陕西: 太白山、朱雀森林公园等 } \\
\text { Shaanxi: Mt. Taibai, Zhuque Forest Park etc. }\end{array}$ \\
\hline 总计 Total & & 215 & \\
\hline
\end{tabular}

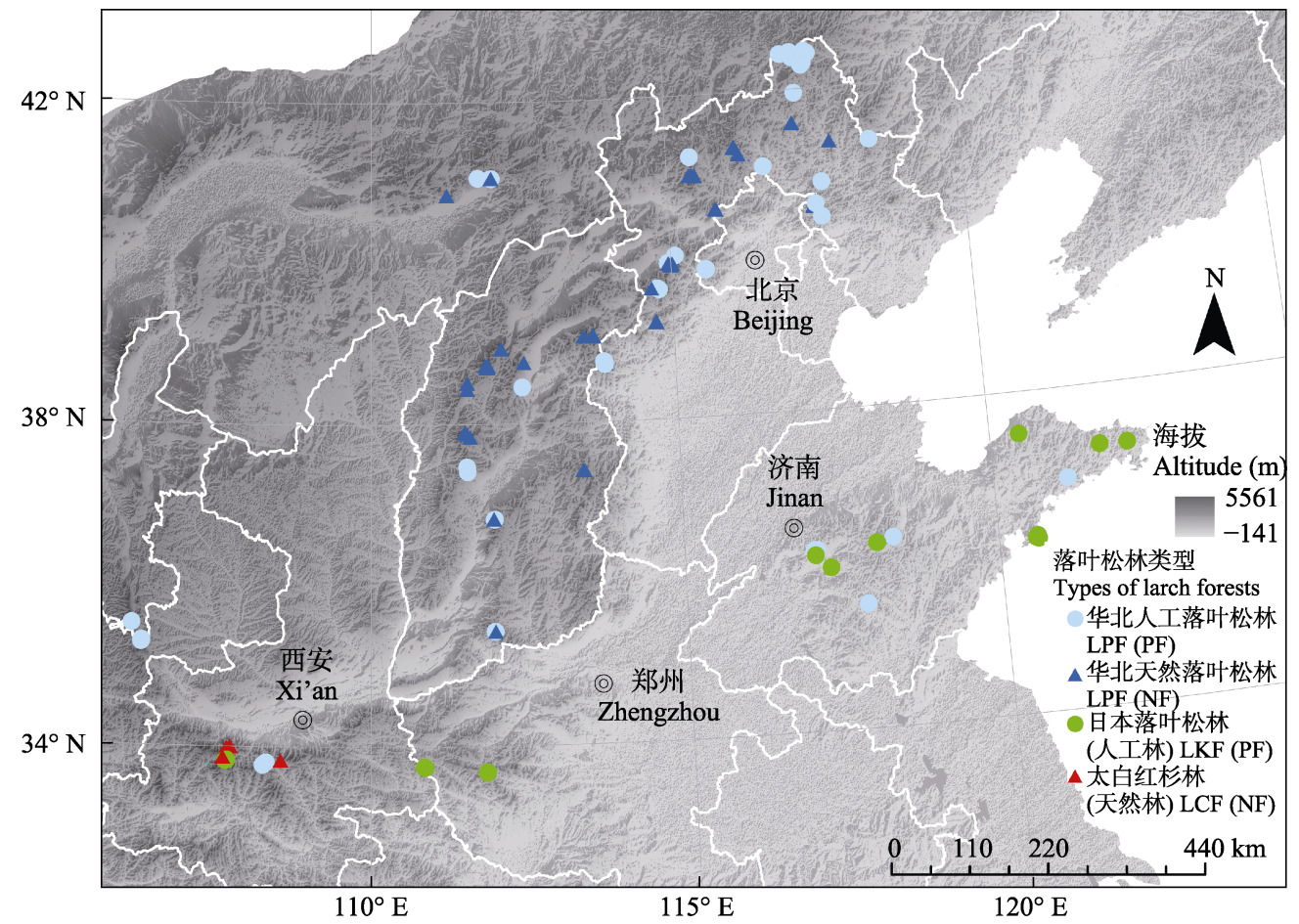

图1 华北地区3种落叶松林样方分布图。

Fig. 1 Sampling sites of the three larch forests in North China.

\section{2 调查方法}

样方调查时间为2000-2017年，面积 $20 \mathrm{~m} \times 30$ $\mathrm{m} 。$ 外业工作时, 记录样方内所有物种的物种名, 分 乔木层、灌木层、草本层分别进行调查。对于乔木 层, 对样方内胸径 $(D B H) \geqslant 3 \mathrm{~cm}$ 的所有乔木进行 每木检尺, 测其 $D B H$ 、树高; 对于灌木层, 将样方划 成 $10 \mathrm{~m} \times 10 \mathrm{~m}$ 的小样方, 并从中选取 2 个进行调查, 记录平均高度、盖度、株数等; 对于草本层, 在每
个 $10 \mathrm{~m} \times 10 \mathrm{~m}$ 小样方内选取 1 个 $1 \mathrm{~m} \times 1 \mathrm{~m}$ 的小样方 进行调查, 记录多度、盖度、高度等(方精云等, 2009)。调查同时记录样地所在的经纬度、海拔及坡 度和坡向等信息。

\section{3 数据统计分析}

计算乔木层物种的重要值。

相对频度 $=\frac{\text { 样方内该种的频度 }}{\text { 样方内全部种的频度总和 }} \times 100 \%$ 
相对优势度 $=$ 样方内该种个体的胸高断面积 /

样方内全部种的胸高断面积总和 $\times 100 \%$

重要值 $=($ 相对频度 + 相对优势度 $) / 2$

基于乔木层物种的胸高断面积, 对 215 个样地 进行典型相关分析 $(\mathrm{CCA})$ 排序。文中气候数据来源 于 WorldClim数据库(www.worldclim.org), 在ArcGIS 10.3支持下, 利用样方的经纬度信息获取所在样点 的气候数据。本文使用的气候因子包括年平均气温 $(M A T)$ 和年降水量 $(M A P)$ 。地形因子包括坡度和 坡向。

选用物种丰富度(即物种数量)表征物种多样性。

用多重比较的方法对比分析3种落叶松的林分 径级结构及树高结构特征。

本研究的数据统计均在R软件(3.4.3)中完成。

\section{2 结果}

\section{1 华北地区落叶松林的地理分布及其与环境因} 子的关系

将华北地区3 种落叶松林的物种矩阵结合地理 因子及环境因子进行 CCA 排序, 其结果如图2所示。 在地理因子与落叶松林物种矩阵的排序中, $\mathrm{CCA}$ 第 一轴反映了海拔和经纬度格局对落叶松林分布的交 互影响，落叶松天然林的分布与海拔正相关而与经 纬度负相关, 大部分落叶松人工林的分布与海拔负 相关而与经纬度正相关; 而CCA第二轴体现的主要 是落叶松林分布的经纬度格局, 随着经纬度的增加, 落叶松林的分布由太白红杉林向日本落叶松林和华 北落叶松林演变(图2A; 表2)。在环境因子与物种矩 阵的排序中, CCA第一轴主要体现了群落沿MAT的 变化格局, 随着 MAT的升高, 落叶松林的天然分布 减少而人工种植分布增加, 落叶松林的类型也由太 白红杉林向华北落叶松林和日本落叶松林演变; CCA第二轴主要体现了坡度分布规律, 华北落叶松 林的分布与坡度大小存在正相关关系, 而日本落叶 松林及太白红杉林的分布与坡度表现为负相关。综 合而言, 华北地区落叶松人工林和天然林有显著的 经纬度分布格局; MAT是华北地区落叶松人工林和 天然林以及 3 种森林类型分布的最重要影响因素(图 2 ; 表2)。

\section{2 华北地区落叶松林的常见物种组成}

华北落叶松天然林乔木层物种主要为华北落叶 松(重要值为74.6\%)、油松(Pinus tabuliformis, 6.0\%)、

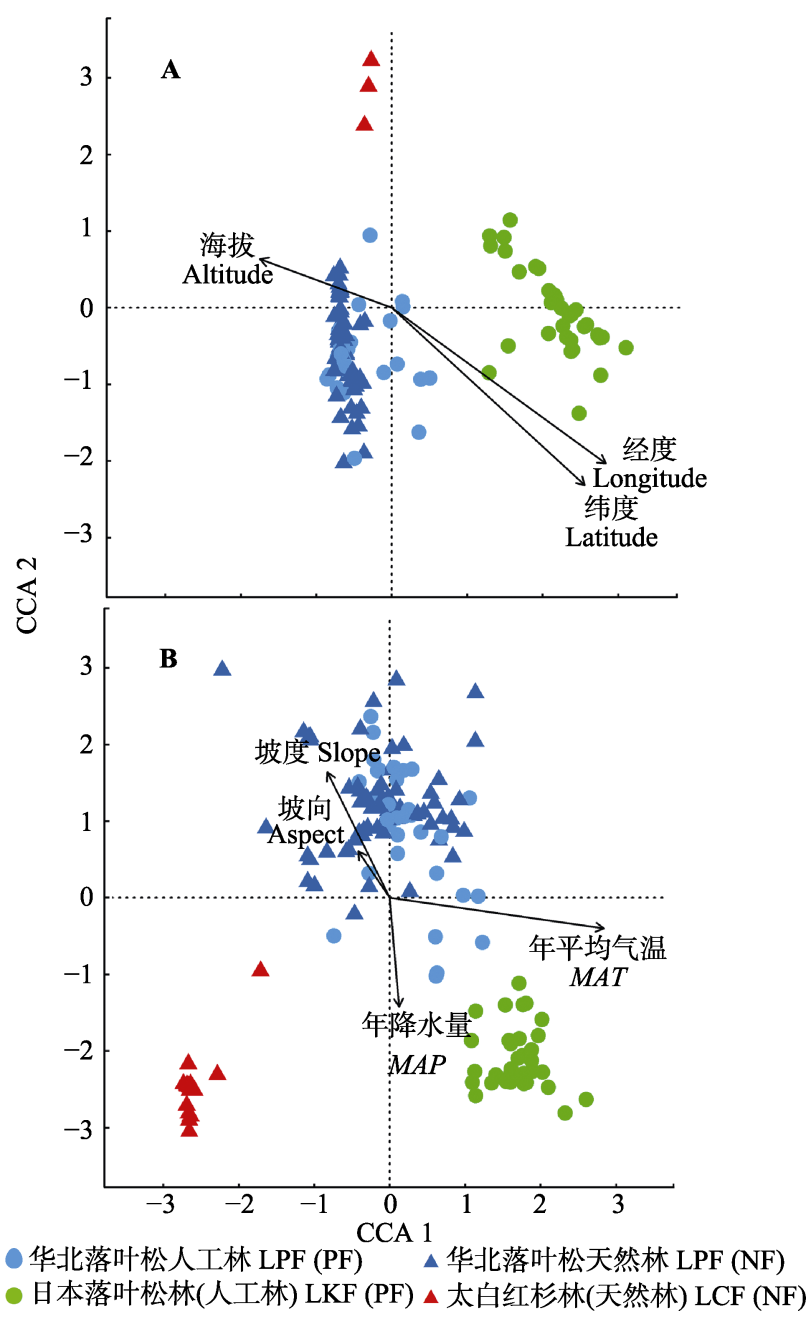

图2 华北地区落叶松林沿地理 $(\mathbf{A})$ 及环境因子 $(\mathbf{B})$ 的典范对 应分析排序图。

Fig. 2 Canonical correspondence analysis ordinations oflarch forests along geographical (A) and environmental variables (B) in North China. Environmental factors include Aspect, Slope, mean annual air temperature (MAT) and mean annual precipitation (MAP). LCF, L. chinensis forest; LKF, L. kaempferi forest; LPF, Larix principis-rupprechtii forest; NF, natural forest; PF, planted forest.

表2 华北地区落叶松林物种矩阵与环境因子及地理因子典范对应分析 排序得分

Table 2 Scores of the canonical correspondence analysis ordinations of larch forests in North China

\begin{tabular}{lrrcc}
\hline 地理因素 Geographical factor & CCA 1 & CCA 2 & $R^{2}$ & $p$ \\
\hline 经度 Longitude & 0.89 & -0.46 & 0.44 & $<0.01$ \\
纬度 Latitude & 0.84 & -0.55 & 0.42 & $<0.01$ \\
海拔 Altitude & -0.96 & 0.27 & 0.13 & $<0.01$ \\
\hline \hline 气候及地形因素 & CCA 1 & CCA 2 & $R^{2}$ & $p$ \\
Climatic and topographical factors & & & & \\
\hline 年降水量 MAP & 0.19 & -0.98 & 0.08 & $<0.01$ \\
年平均气温 MAT & 0.99 & -0.11 & 0.53 & $<0.01$ \\
坡度 Slope & -0.65 & 0.76 & 0.15 & $<0.01$ \\
坡向 Aspect & -0.75 & 0.66 & 0.03 & 0.1 \\
\hline
\end{tabular}

$M A P$, mean annual precipitation; MAT, mean annual air temperature. 
红桦(Betula albosinensis, 6.0\%)及白桦(B. platyphylla, $3.0 \%)$; 华北落叶松人工林乔木层物种主要为华北 落叶松(88.7\%)、油松(2.8\%)、辽东桤木(Alnus sibirica, $1.8 \%$ )及蒙古栋(Quercus mongolica, $1.5 \%$ ); 日本落 叶松林乔木层物种主要为日本落叶松 $(70.2 \%)$ 、水榆 花楸 (Sorbus alnifolia, 5.3\%)、白檀 (Symplocos paniculata，4.2\%)及三桠乌药(Lindera obtusiloba, $2.8 \%)$; 太白红杉林乔木层物种主要为太白红杉 (81.2\%)、巴山冷杉(Abies fargesii, 8.1\%)、金背杜鹃 (Rhododendron clementinae subsp. aureodorsale, $5.4 \%)$ )糙皮桦(B. utilis, 2.2\%)(表3)。

\section{3 华北地区落叶松林的物种多样性}

华北落叶松天然林乔、灌、草层的平均物种丰 富度分别为 $3.1 、 5.8$ 和 11.4 ; 华北落叶松人工林乔、 灌、草层的平均物种丰富度分别为2.5、4.7和20.4; 日本落叶松林分别为5.1、13.8和20.4; 太白红杉林 分别为 $2.2 、 7.7$ 和 29.6 ; 所有天然林分别为 $2.9 、 6.2$ 和 21.8 ; 所有人工林分别为 $3.5 、 7.9$ 和 20.4 (表 4 )。 3 种落叶松林乔木层物种丰富度最大值分别是: $11 、 11$ 和6; 灌木层: $29 、 38$ 和 22 ; 草本层: 55 、56和73 (表 4)。所有天然林和所有人工林的物种丰富度没有显 著差异 $(p>0.05)$, 但是 3 种不同类型落叶松林乔、 灌、草层的物种丰富度差异显著 $(p<0.05)$ (图3; 表 $4)$ 。具体而言, 日本落叶松林乔木层物种丰富度显 著大于华北落叶松林和太白红杉林 $(p<0.05)$, 华北 落叶松林与太白红杉林的乔木层物种丰富度没有差
异 $(p>0.05)$; 日本落叶松林灌木层物种丰富度显著 大于华北落叶松林 $(p<0.05)$, 但与太白红杉林没有 显著差异 $(p>0.05)$, 华北落叶松天然林灌木层物种 丰富度与太白红杉林没有显著差异 $(p>0.05)$, 但是 华北落叶松人工林的灌木层物种丰富度显著小于太 白红杉林 $(p<0.05)$; 太白红杉林的草本层物种丰富 度显著大于日本落叶松林及华北落叶松林 $(p<0.05)$, 日本落叶松林与华北落叶松林的草本层物种丰富度 没有显著差异 $(p>0.05)$ (图3)。

\section{4 华北地区落叶松林的群落结构}

三种落叶松林中优势种的胸径和树高结构如表 5所示。日本落叶松的平均胸径最大, 太白红杉次之, 华北落叶松的平均胸径最小。日本落叶松的平均树 高最高, 华北落叶松次之, 太白红杉最低。三种落叶 松胸径、树高的偏度系数均大于 0 ; 峰度系数均大于 3 。从森林起源来看, 落叶松天然林优势种的胸径大 于人工林, 树高小于人工林, 无论天然林还是人工 林均偏度系数大于 0 , 峰度系数大于 3 (表 5 )。

\section{5 华北地区落叶松林的群落结构和多样性与地 理及气候因子的关系}

地理和气候因子对华北地区落叶松林的群落结 构和物种多样性影响显著 $(p<0.05)$ 。就总体而言, 除最大树高与经度的关系不显著 $(p>0.05)$ 以外, 落 叶松林的最大胸径和最大树高及总体的物种丰富度 随着经纬度的增加而显著降低 $(p<0.05)$ (图4), 随着 $M A P$ 的增加而显著增加 $(p<0.05)($ 图4D、4H、4L)。

表3 华北地区3种落叶松林乔木层主要物种的重要值

Table 3 Important value of the main tree species in the canopy of three larch forests in North China

\begin{tabular}{|c|c|c|c|c|c|c|c|}
\hline $\begin{array}{l}\text { 华北落叶松(人工林) } \\
\text { LPF (PF) }\end{array}$ & $\begin{array}{l}\text { 重要值 } \\
\text { IV }(\%)\end{array}$ & \begin{tabular}{|l} 
华北落叶松(天然林) \\
LPF (NF)
\end{tabular} & $\begin{array}{l}\text { 重要值 } \\
\text { IV }(\%)\end{array}$ & \begin{tabular}{|l} 
日本落叶松林(人工林) \\
LKF (PF)
\end{tabular} & $\begin{array}{l}\text { 重要值 } \\
\text { IV }(\%)\end{array}$ & $\begin{array}{l}\text { 太白红杉林(天然林) } \\
\text { LCF (NF) }\end{array}$ & $\begin{array}{l}\text { 重要值 } \\
\text { IV }(\%)\end{array}$ \\
\hline $\begin{array}{l}\text { 华北落叶松 } \\
\text { Larix principis- } \\
\text { rupprechtii } \\
\text { 油松 Pinus tabuliformis } \\
\text { 辽东桤木 } \\
\text { Alnus sibirica } \\
\text { 蒙古栋 } \\
\text { Quercus mongolica } \\
\text { 白桦 } \\
\text { Betula platyphylla } \\
\text { 红桦 B. albosinensis } \\
\text { 华山松 Pinus armandii } \\
\text { 其他种 Other species }\end{array}$ & $\begin{array}{l}0.8 \\
0.5\end{array}$ & \begin{tabular}{|l} 
华北落叶松 \\
L. principis-rupprechtii \\
油松 P. tabuliformis \\
红桦 B. albosinensis \\
白桦 B. platyphylla \\
白扞 Picea meyeri \\
青扞 P. wilsonii \\
黑桦 B. dahurica \\
山杨 Populus davidiana \\
红皮云杉 P. koraiensis \\
胡桃楸 Juglans mandshurica \\
辽东栋 Q. wutaishanica \\
其他种 Other species
\end{tabular} & $\begin{array}{l}6.0 \\
6.0 \\
3.0 \\
1.5 \\
1.5 \\
1.2 \\
0.9 \\
0.9 \\
0.8 \\
0.5 \\
3.4\end{array}$ & $\begin{array}{l}\text { 日本落叶松 L. kaempferi } \\
\text { 水榆花楸 Sorbus alnifolia } \\
\text { 白檀 Symplocos paniculata } \\
\text { 三桠乌药 Lindera obtusiloba } \\
\text { 麻栋 Q. acutissima } \\
\text { 漆 Toxicodendron vernicifluum } \\
\text { 日本花柏 Chamaecyparis pisifera } \\
\text { 赤松 P. densiflora } \\
\text { 胡桃楸 Juglans mandshurica } \\
\text { 蓝果树 Nyssa sinensis } \\
\text { 辽东栋 Q. wutaishanica } \\
\text { 椴树 Tilia tuan } \\
\text { 水曲柳 Fraxinus mandschurica } \\
\text { 华山松 P. armandii } \\
\text { 刺槐 Robinia pseudoacacia } \\
\text { 其他种 Other species }\end{array}$ & $\begin{array}{r}70.2 \\
5.3 \\
4.2 \\
2.8 \\
2.1 \\
2.0 \\
1.9 \\
0.9 \\
0.8 \\
0.7 \\
0.7 \\
0.6 \\
0.6 \\
0.6 \\
0.6 \\
6.3\end{array}$ & \begin{tabular}{|l} 
太白红杉 L. chinensis \\
巴山冷杉 Abies fargesii \\
金背杜鹃 \\
Rhododendron clementinae \\
subsp. aureodorsale \\
糙皮桦 B. utili \\
陕甘花楸 \\
Sorbus koehneana \\
白桦 B. platyphylla \\
其他种 Other species
\end{tabular} & $\begin{array}{l}2.2 \\
1.5 \\
0.6 \\
1.0\end{array}$ \\
\hline
\end{tabular}

表中植物名称参照《中国植物志》中文版(中国植物志编辑委员会, 2004)。

Plant names refer to Flora Republicae Popularis Sinicae (The Editorial Committee of Flora of China, 2004). IV, important value; LCF, L. chinensis forest; LKF, L. kaempferi forest; LPF, L. principis-rupprechtii forest; NF, natural forest; PF, planted forest.

www.plant-ecology.com 

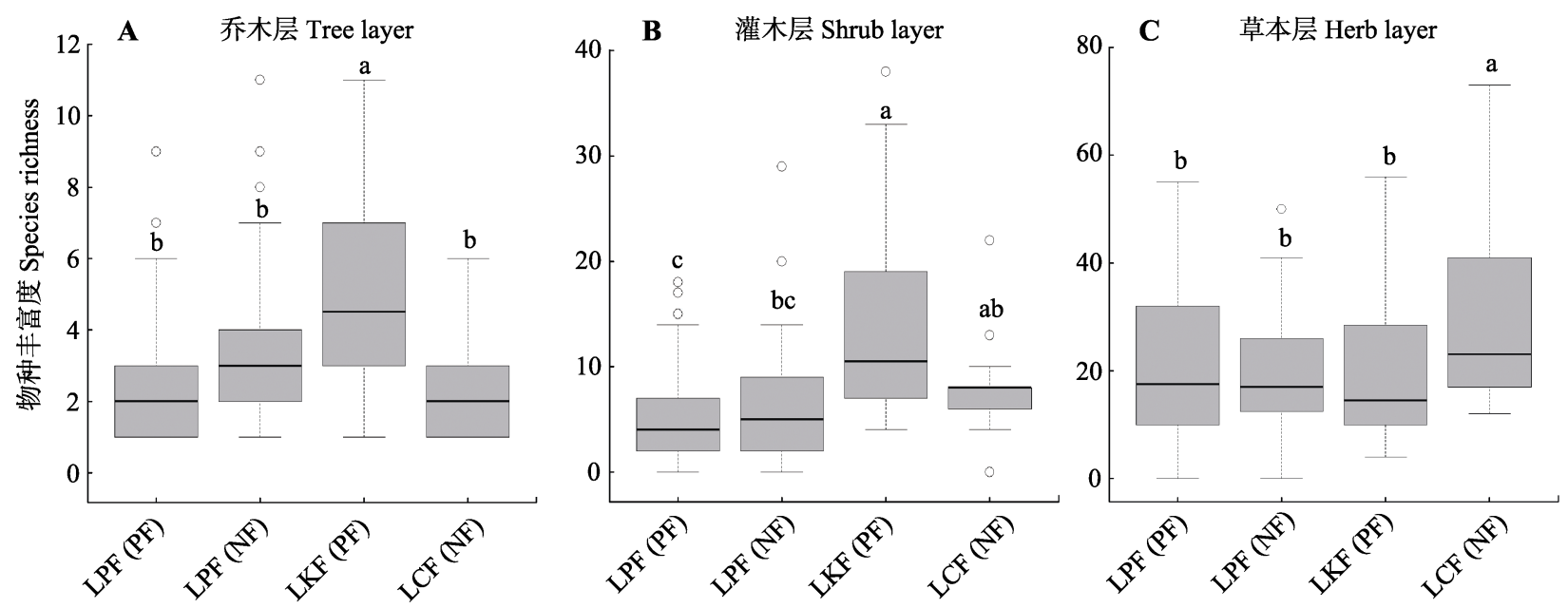

图3 华北地区三种落叶松林乔木层 $(\mathbf{A})$ 、灌木层 $(\mathbf{B})$ 和草本层 $(\mathbf{C})$ 的物种丰富度。不同小写字母代表多重比较的结果。其中LPF、

LKF和LCF分别表示华北落叶松林、日本落叶松林和太白红杉林, NF和PF分别表示表示天然林和人工林。

Fig. 3 Species richness of the tree (A), shrub (B) and herb (C) layers in the Larix principis-rupprechtii, L. kaempferi and L. chinensis forests in North China. Different lowercase letters mean the result of multiple comparisons. LCF, L. chinensis forest; LKF, L. kaempferi forest; LPF, L. principis-rupprechtii forest; NF, natural forest; PF, planted forest.

表4 华北地区落叶松林的物种丰富度

Table 4 Species richness of larch forests in North China

\begin{tabular}{|c|c|c|c|c|c|}
\hline \multirow{2}{*}{$\begin{array}{l}\text { 落叶松林类型 } \\
\text { Forest type } \\
\text { 华北落叶松(人工林) LPF (PF) }\end{array}$} & $\begin{array}{l}\text { 乔木层 } \\
\text { Tree layer }\end{array}$ & $\begin{array}{c}\text { 灌木层 } \\
\text { Shrub layer }\end{array}$ & \multicolumn{2}{|c|}{$\begin{array}{c}\text { 草本层 } \\
\text { Herb layer }\end{array}$} & $\begin{array}{l}\text { 总体 } \\
\text { Total }\end{array}$ \\
\hline & $2.5 \pm 2.1^{\mathrm{b}} \quad(1-9)$ & $4.7 \pm 4.1^{\mathrm{c}} \quad(0-18)$ & $20.4 \pm 15.8^{b}$ & $(0-55)$ & $27.2 \pm 17.7^{\mathrm{b}} \quad(0-63)$ \\
\hline 华北落叶松(天然林) LPF (NF) & $3.1 \pm 2.1^{\mathrm{b}} \quad(1-11)$ & $5.8 \pm 5.0^{\mathrm{bc}} \quad(0-29)$ & $11.4 \pm 19.1^{\mathrm{b}}$ & $(0-50)$ & $27.5 \pm 13.8^{\mathrm{b}} \quad(1-65)$ \\
\hline 日本落叶松林(人工林) LKF (PF) & $5.1 \pm 2.9^{\mathrm{a}} \quad(1-11)$ & $13.8 \pm 9.1^{\mathrm{a}}$ & $20.4 \pm 15.1^{\mathrm{b}}$ & $(4-56)$ & $37.4 \pm 22.4^{\mathrm{ab}}$ \\
\hline 太白红杉林(天然林) LCF (NF) & $2.2 \pm 1.5^{\mathrm{b}} \quad(1-6)$ & $7.7 \pm 3.6^{\mathrm{ab}} \quad(0-22)$ & $29.6 \pm 15.8^{\mathrm{a}}$ & $(12-73)$ & $39.3 \pm 17.9^{\mathrm{a}} \quad(17-98)$ \\
\hline 所有天然林 All natural forest & $2.9 \pm 2.0^{\mathrm{a}} \quad(1-11)$ & $6.2 \pm 4.7^{\mathrm{a}} \quad(0-29)$ & $21.8 \pm 13.4^{\mathrm{a}}$ & $(0-73)$ & $30.5 \pm 15.8^{\mathrm{a}}$ \\
\hline 所有人工林 All planted forest & $3.5 \pm 2.7^{\mathrm{a}} \quad(1-11)$ & $7.9 \pm 7.6^{\mathrm{a}} \quad(0-38)$ & $20.4 \pm 15.5^{\mathrm{a}}$ & $(0-56)$ & $30.8 \pm 20^{\mathrm{a}} \quad(1-81)$ \\
\hline
\end{tabular}

数据表达为平均值土标准偏差及(最小值-最大值)。不同小写字母代表多重比较的结果。

Values represent mean $\pm S D$ and (minimum - maximum) value. Different lowercase letters mean the result of multiple comparisons. LCF, L. chinensis forest; LKF, L. kaempferi forest; LPF, L. principis-rupprechtii forest; NF, natural forest; PF, planted forest.

表5 华北地区3种落叶松林中优势种的胸径、树高结构

Table 5 Diameter at breast height $(D B H)$ and height structure of dominant species in three larch forests in North China

\begin{tabular}{|c|c|c|c|c|c|c|}
\hline $\begin{array}{l}\text { 胸径/树高 } \\
\mathrm{DBH} / \text { Height }\end{array}$ & $\begin{array}{l}\text { 优势种 } \\
\text { Dominant species }\end{array}$ & $\begin{array}{c}\text { 数量 } \\
\text { Number }\end{array}$ & $\begin{array}{c}\text { 均值 } \pm \text { 标准偏差 } \\
\text { Mean } \pm S D\end{array}$ & $\begin{array}{c}\text { 最小值-最大值 } \\
\text { Min-Max }\end{array}$ & $\begin{array}{l}\text { 偏度系数 } \\
\text { Skewness }\end{array}$ & $\begin{array}{l}\text { 峰度系数 } \\
\text { Kurtosis }\end{array}$ \\
\hline \multirow[t]{6}{*}{ 胸径 DBH(cm) } & 华北落叶松(人工林) LPF (PF) & 4251 & $15.1 \pm 6.4^{\mathrm{d}}$ & $3.0-36.2$ & 0.2 & 2.2 \\
\hline & 华北落叶松(天然林) LPF (NF) & 4464 & $18.0 \pm 7.5^{\mathrm{c}}$ & $3.0-75.8$ & 0.7 & 4.4 \\
\hline & 日本落叶松(人工林) LKF (PF) & 1463 & $20.7 \pm 8.4^{\mathrm{a}}$ & $3.2-56.0$ & 0.8 & 3.7 \\
\hline & 太白红杉(天然林) LCF (NF) & 1278 & $19.5 \pm 9.8^{b}$ & $3.0-80.0$ & 0.8 & 4.5 \\
\hline & 所有天然林 All natural forest & 5742 & $18.3 \pm 8.1^{\mathrm{a}}$ & $3.0-80.0$ & 0.8 & 4.8 \\
\hline & 所有人工林All planted forest & 5714 & $16.5 \pm 7.4^{\mathrm{b}}$ & $3.0-56.0$ & 0.7 & 3.8 \\
\hline \multirow[t]{6}{*}{ 树高 Height (m) } & 华北落叶松(人工林) LPF (PF) & 4251 & $11.3 \pm 4.2^{\mathrm{c}}$ & $2.2-35.5$ & 0.6 & 3.6 \\
\hline & 华北落叶松(天然林) LPF (NF) & 4464 & $12.3 \pm 4.3^{\mathrm{b}}$ & $2.0-30.0$ & 0.3 & 3.2 \\
\hline & 日本落叶松(人工林) LKF (PF) & 1463 & $17.6 \pm 8.2^{\mathrm{a}}$ & $2.3-39.5$ & 0.6 & 2.8 \\
\hline & 太白红杉(天然林) LCF (NF) & 1278 & $9.1 \pm 4.8^{\mathrm{d}}$ & $2.0-30.0$ & 2.0 & 8.2 \\
\hline & 所有天然林 All natural forest & 5742 & $11.6 \pm 4.6^{\mathrm{b}}$ & $2.0-30.0$ & 0.6 & 3.6 \\
\hline & 所有人工林 All planted forest & 5714 & $12.9 \pm 6.1^{\mathrm{a}}$ & $2.2-39.5$ & 1.4 & 5.6 \\
\hline
\end{tabular}

不同小写字母代表多重比较的结果。

Different lowercase letters mean the result of multiple comparisons. LCF, L. chinensis forest; LKF, L. kaempferi forest; LPF, L. principis-rupprechtii forest; NF, natural forest; PF, planted forest. 

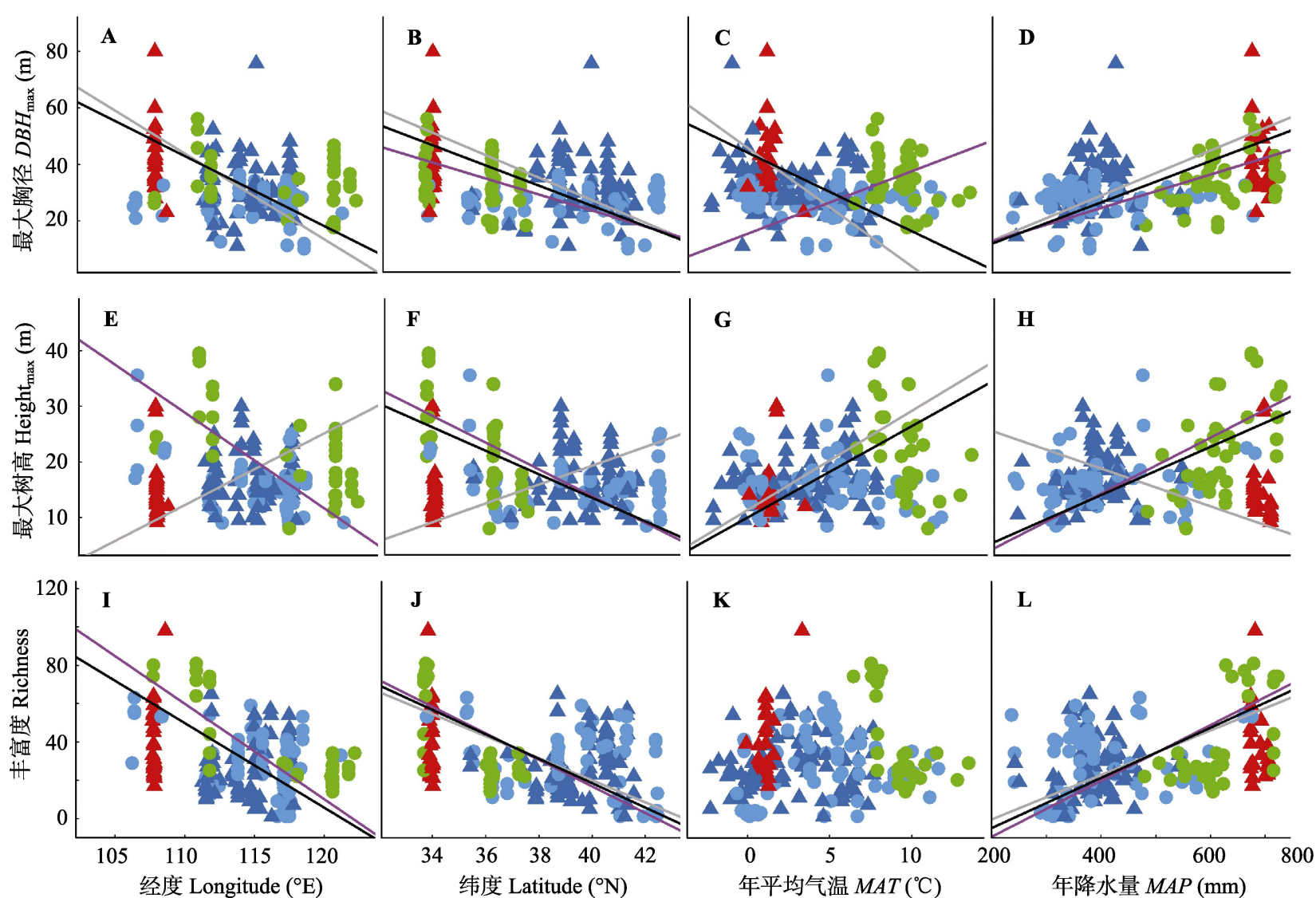

- 华北落叶松人工林 LPF (PF) $\Delta$ 华北落叶松天然林 LPF (NF) - 日本落叶松林(人工林) LKF (PF) $\Delta$ 太白红杉林(天然林) LCF (NF)

一 落叶松天然林 NF 一落叶松人工林 PF 一 落叶松林总体 LF

图4 华北地区落叶松林的群落结构和物种丰富度与经纬度及年平均气温和年降水量之间的关系。

Fig. 4 Changes in community structure and species richness with latitude, longitude, mean annual temperature (MAT) and precipitation $(M A P)$ for the larch forests in North China. The structure measurements of forests include the maximum diameter at breast height $\left(D B H_{\max }\right)$ and height $\left(\mathrm{Height}_{\max }\right)$. LCF, L. chinensis forest; LKF, L. kaempferi forest; LPF, L. principis-rupprechtii forest; NF, natural forest; PF, planted forest.

此外, MAT对华北地区落叶松林的总物种丰富度影 响不大(图4K), 但是对其群落结构影响显著 $(p<$ $0.05)$ 。随着MAT的升高, 落叶松林的最大胸径显著 降低而最大树高却显著增加 $(p<0.05)$ (图4C、4G)。 从森林起源来看, 落叶松天然林的最大树高随着经 纬度及MAT的增加而显著增加 $(p<0.05)$, 随MAP的 增加而显著降低 $(p<0.05)$; 与此相反的, 其最大胸 径却随着经纬度及 $M A T$ 的增加而显著降低 $(p<0.05)$, 随 $M A P$ 的增加而显著增加 $(p<0.05)$; 其物种丰富度 与经度及MAT没有显著相关性 $(p>0.05)$, 随着纬度 的增加而显著降低 $(p<0.05)$, 随着 $M A P$ 的增加而显 著增加 $(p<0.05)$ (图4)。落叶松人工林的群落结构和 物种多样性与地理及气候因子间的关系与落叶松天 然林及总体的规律基本一致。但是, 随经度的增加, 天然林的最大树高显著增加而人工林的最大树高显 著降低 $(p<0.05)$ (图4I); 随MAT的增加, 落叶松天然
林的最大胸径显著降低而人工林的最大胸径显著增 加 $(p<0.05)$ (图4C); 随着 $M A P$ 的增加, 落叶松天然 林的最大树高显著降低而人工林的最大树高显著增 加 $(p<0.05)$ (图4H)。

\section{3 讨论}

植物群落结构可以反映出群落的整体状态。3 种落叶松林胸径和树高频度分布的偏度系数大于 0 且峰度系数大于 3 (表5), 即 3 种落叶松林的胸径和 树高结构总体均呈右偏分布且其径级大小和高度大 小相对集中, 表明 3 种落叶松林均处于相对稳定的 演替阶段(Tyrrell \& Crow, 1994; Aiba \& Kitayama, 1999; Fang et al., 2012)。匡旭等(2014)对中国东北长 白山落叶松林的研究结果显示, 长白落叶松 (L. olgensis) 有较多DBH $<10 \mathrm{~cm}$ 的个体, 群落处于生长 状态。赵文智(1997)对河北坝上华北落叶松人工林 
的研究表明, 30 年华北落叶松成熟林林分稳定, 有 天然更新的潜力。我们的结果与以上研究结果一致。

物种丰富度是测度物种多样性的一个重要维度 (Gaston, 2000)。华北地区, 3种落叶松林的物种丰富 度总体比较丰富, 乔、灌、草层的物种丰富度有显 著的差异(图3; 表4)。这与 3 种落叶松林的物种组成、 气候条件以及乔木层郁闭度等因素有关(Wang et al., 2009; Mölder et al., 2014)。具体而言, 太白红杉林为 秦岭山地原始林(雷明德, 1999), 华北落叶松林也多 为人工林或次生林(刘濂, 1996), 两种落叶松林优势 种太白红杉及华北落叶松的重要值很高(表3), 大部 分甚至是纯林, 因而它们的乔木层的物种丰富度很 低(表4), 没有显著差异(图3A)。而日本落叶松林虽 然是人工林, 但其分布海拔低于华北落叶松林和太 白红杉林, 拥有更好的水热条件, 群落物种更为丰 富; 通常与其他物种混交, 其乔木层优势种日本落 叶松的重要值只有 $70.2 \%$ (表3), 因而其乔木层的物 种丰富度显著大于华北落叶松林和太白红杉林(图 $3 \mathrm{~A})$ 。此外, 日本落叶松林与华北落叶松林均分布于 中低海拔区域, 乔木层郁闭度大, 林下植物尤其是 草本植物的生长受到影响, 其草本层丰富度相对较 低, 没有显著差异(图3C)。而太白红杉林位于秦岭 山地高海拔区域, 乔木层郁闭度相对较小, 有利于 林下植物的生长, 其林下草本层的物种丰富度显著 大于华北落叶松林和日本落叶松林(图3C)。但是, 也正是由于分布海拔高的影响, 其林下的生境条件 较差, 所以对比华北地区纬度位置相差不大的日本 落叶松林, 其灌木层物种丰富度没有显著优势 (图 $3 \mathrm{~B})$ 。

华北地区落叶松林的群落结构特征及物种多样 性与其分布的地理位置和气候条件紧密相关。总体 而言, 除最大树高与经度的关系不显著以外, 华北 地区落叶松林最大胸径和最大树高及总体的物种丰 富度均随着经纬度的增加而显著降低(图4A、4D、 $4 \mathrm{E} 、 4 \mathrm{~F} 、 4 \mathrm{I} 、 4 \mathrm{~J})$, 这与前人在全球地理格局的研究结 果一致(Gaston, 2000; Moles et al., 2009; Tao et al., 2016)。此外, 诸多的研究表明, 水分条件是乔木胸 径和高度及植物群落物种丰富度的重要影响因子 (Gaston, 2000; Zhang et al., 2013; Tao et al., 2016)。 在华北地区, 落叶松林最大胸径与最大树高及其总 体的物种丰富度随着 $M A P$ 的增加而增加(图4D、4H、 4L), 与前人的研究结果相符(Gaston, 2000; Moles et al., 2009; Zhang et al., 2013)。而与经纬度和MAP对 华北地区落叶松林最大胸径和最大树高的影响的一 致性不同, MAT对华北地区落叶松林最大胸径与最 大树高的影响正好相反(图4C、4G)。我们的结果显 示：华北地区落叶松林最大胸径随 $M A T$ 的增加而 降低, 随 $M A P$ 的增加而增加 (图 $4 \mathrm{C} 、 4 \mathrm{G}$ ), 与 Yan等 (2006)对鼎湖山亚热带常绿阔叶林优势乔木胸径的 研究及 Tao等(2016)对全球树高的研究结果一致。落 叶松属植物为阳性物种, 作为林线植被, 气候变暖 对落叶松的生长及群落更新可能是有利的(Devi et al., 2008)。在全球气候变暖的背景下, 华北地区的 落叶松林更趋向于垂直生长。

从森林起源来看, 落叶松天然林和落叶松人工 林的群落结构特征及物种多样性与地理及气候因子 之间的关系，与落叶松林总体的基本一致。其在地 理因子上的差异主要体现在最大树高上, 落叶松人 工林的最大树高随经纬度的增加而减少, 与前人在 全球地理格局的研究结果一致(Gaston, 2000; Moles et al., 2009; Tao et al., 2016)。但是落叶松天然林的 最大树高随经纬度的增加而增加, 与前人的研究结 果(Gaston, 2000; Moles et al., 2009; Tao et al., 2016) 相反, 其原因可能与海拔高度有关。华北地区低纬 度和经度位置偏西的落叶松天然林主要是太白红杉 林(图1), 其分布海拔高, 树高相对低矮(表5), 而高 纬度位置及经度位置偏东的落叶松天然林为华北落 叶松林, 其分布海拔较太白红杉林低(郑万均和傅 立国, 1978), 树高更高(表5), 即华北地区落叶松林 与地理因素的关系主要由落叶松人工林所主导。落 叶松人工林和落叶松天然林在气候因子上的差异体 现在最大胸径与 $M A T$ 以及最大树高与 MAP的关系 上(图4C、4H)。落叶松天然林的最大胸径和最大树 高分别随 $M A T$ 和 $M A P$ 的增大而减小, 而落叶松人工 林的最大胸径和最大树高分别随 $M A T$ 和 $M A P$ 的增 大而增大。落叶松林总体最大胸径与气候条件的关 系与落叶松天然林一致, 最大树高与气候条件的关 系与落叶松人工林一致, 而对比落叶松天然林和落 叶松人工林优势种的胸径树高, 落叶松天然林优势 种的胸径显著大于人工林, 而树高显著小于人工林 (表5), 即华北地区落叶松林与MAT的关系主要受落 叶松天然林的影响, 而与 $M A P$ 的关系主要受落叶松 人工林的影响。

前人基于大尺度的研究表明, 气候因子尤其是 
环境能量因子对物种丰富度的影响显著(Wang et al., 2012)。但我们的结果似乎并不支持这一结论。本研 究中, MAT对华北地区落叶松林的物种丰富度没有 显著影响(图4K)。这可能与研究对象的差异有关。 Wang等(2012)的研究是基于木本植物物种丰富度的 结果, 而本研究中的研究结果是基于落叶松林木本 植物及草本植物总的物种丰富度的结果。由表4可知, 华北地区落叶松林总体的物种丰富度中草本植物所 占的比重最大, 因而其对环境条件的响应与木本植 物的不同。

除地理及环境因子的影响外，人为干扰也是影 响森林群落结构和物种丰富度的重要影响因子。对 落叶松天然林而言, 人为干扰可能主要体现在旅游 方面。近年来, 由于生态旅游的兴起, 大量的游客涌 入到自然保护区的核心区, 砍椽(搭设旅游接待帐 篷用)、烧柴(取暖和生活用柴)以及生活垃圾污染等 对山地环境产生重要影响, 诸如本文研究区域的秦 岭太白山保护区就是近年来生态旅游的一大热点地 区(刘香妮, 2001)。对落叶松人工林而言, 其初期的 抚育间伐对落叶松幼龄林及中龄林的群落结构和物 种丰富度影响甚大(李国雷等, 2009; 李淑辉等, 2012; 郭琳等, 2014)。而我们调查的落叶松林大部 分为成熟林, 甚至部分已经向人工天然混交林状态 发展, 群落结构及物种丰富度已经相对稳定。对比 落叶松天然林和落叶松人工林的胸径树高结构发现, 落叶松天然林的胸径大于人工林, 而其树高则小于 人工林(表5)。由于落叶松人工林主要营造于中低海 拔地带, 而现存的落叶松天然林主要在高海拔区 域。所以这除了可能与森林经营管理有关外, 落叶 松天然林和人工林的分布海拔对其胸径树高结构的 影响可能更大。对比落叶松天然林与人工林的物种 丰富度并无显著差异(表4)。其原因可能是由于华北 地区的落叶松人工林属于三北防护林工程的水土涵 养林，对于成过熟林乃至有天然化趋势的人工林, 人为的经营管理活动较少, 故而其群落结构和物种 丰富度受到的影响可能较小(表 4 , 表5), 而放牧等 活动对该地区中低海拔落叶松人工林的影响或许 更大。

\section{参考文献}

Aiba S, Kitayama K (1999). Structure, composition and species diversity in an altitude-substrate matrix of rain forest tree communities on Mount Kinabalu, Borneo. Plant Ecology,
$140,139-157$.

Chen DS, Sun XM, Zhang SG (2016). Biomass, carbon storage and nutrient characteristics in Larix kaempferi plantations at different stand ages. Chinese Journal of Applied Ecology, 27，3759-3768. [陈东升, 孙晓梅, 张守攻 (2016). 不同年龄日本落叶松人工林生物量、碳储量及养分特 征. 应用生态学报, 27, 3759-3768.]

Cheng WC (1983). Chinese Dendrology. Vol. 1. China Forestry Publishing House, Beijing. [郑万均 (1983). 中国树木志 (第1卷). 中国林业出版社, 北京.]

Cheng WC, Fu LK (1978). Gymnospermae. In: Editorial Committee of Flora of China, Chinese Academy of Sciences. Flora of China. Science Press, Beijing. 169-196. [郑万均, 傅立国 (1978). 裸子植物门. 出自中国科学 院中国植物志编辑委员会编著. 中国植物志. 科学出版 社, 北京. 169-196.]

Devi N, Hagedorn F, Moiseev P, Bugmann H, Shiyatov S, Mazepa V, Rigling A (2008). Expanding forests and changing growth forms of Siberian larch at the Polar Urals treeline during the 20th century. Global Change Biology, 14, 1581-1591.

Duan RY, Wang XA, Huang MY, Wang ZG, Wu GL (2010). Ecological characteristics of Larix chinensis population near timberline on Taibai Mountain in China. Acta Ecologica Sinica, 30, 519-526. [段仁燕, 王孝安, 黄敏 毅, 王志高, 吴甘霖 (2010). 太白山林线附近太白红杉 种群的生态特征. 生态学报, 30, 519-526.]

Editorial Committee of Flora of China (2004). Flora of China. Science Press, Beijing. [中国植物志编辑委员会 (2004). 中国植物志. 科学出版社, 北京.]

Fang JY, Wang XP, Liu YN, Tang ZY, White PS, Sanders NJ (2012). Multi-scale patterns of forest structure and species composition in relation to climate in northeast China. Ecography, 35, 1072-1082.

Fang JY, Wang XP, Shen ZH, Tang ZY, He JS, Yu D, Jiang Y, Wang ZH, Zheng CY, Zhu JL, Guo ZD (2009). Methods and protocols for plant community inventory. Biodiversity Science, 17，533-548. [方精云, 王襄平, 沈泽吴, 唐志 尧, 贺金生, 于丹, 江源, 王志恒, 郑成洋, 朱江玲, 郭 兆迪 (2009). 植物群落清查的主要内容、方法和技术规 范. 生物多样性, 17, 533-548.]

Gaston KJ (2000). Global patterns in biodiversity. Nature, 405, 220-227.

Guo H (2004). Studies on Spatial Pattern of Larix chinensis Populations in Qinling Mountain. Master degree dissertation, Shaanxi Normal University, Xi'an. 20-31. [郭华 (2004). 秦岭太白红杉种群空间分布格局研究. 硕士学 位论文, 陕西师范大学, 西安. 20-31.]

Guo L, Zhu Q, Zhang BG, Yu J, Lin L, Zhou GX (2014). Research on tending thinning of Japanese larch forest in the Sichuan Basin. Journal of Sichuan Forestry Science and Technology, 35(6), 64-68. [郭琳, 朱琴, 张保刚, 余军,

www.plant-ecology.com 
林林, 周桂香 (2014). 四川盆地日本落叶松林抚育间伐 研究. 四川林业科技, 35(6), 64-68.]

Han YY (2006). Study on Effect of the Climatic Factors on the Increment of Larix leptolepis in Funiu Mountain in Western Henan. Master degree dissertation, Henan Agricultural University, Zhengzhou. 20-40. [韩艳英 (2006). 气象因 子对豫西伏牛山区日本落叶松生长量影响研究. 硕士 学位论文, 河南农业大学, 郑州. 20-40.]

Ji WJ, Cheng XQ, Han HR, Kang FF, Yang J, Zhu J, Zhao J, Bai YC, Ma JY (2016). The biomass and nutrient distribution in Larix principis-ruppechtii Magyr plantations at different forest age. Chinese Journal of Applied and Environmental Biology, 22, 277-284. [纪文婧, 程小琴, 韩海 荣, 康峰峰, 杨杰, 朱江, 赵敬, 白英辰, 马俊勇 (2016). 不同林龄华北落叶松人工林生物量及营养元素 分布特征. 应用与环境生物学报, 22, 277-284.]

Kong LW, Chen XW, Lu SW, Li SN, Chen B, Gao C, Shi Y, Yang XY (2014). Relationships among growth Larix principisrupprechtii, herbaceous plants diversity and landform. Bulletin of Soil and Water Conservation, 34, 60-66. [孔令伟, 陈祥伟, 鲁绍伟, 李少宁, 陈波, 高琛, 石媛, 杨小燕 (2014). 华北落叶松林木生长、草本植物多样性及地形 因子之间的关系. 水土保持通报, 34, 60-66.]

Kuang X, Xing DL, Zhang ZC, Song HJ, Wang YY, Fang S, Yuan ZQ, Ye J, Lin F, Wang XG, Hao ZQ (2014). Species composition and community structure of a spruce-fir forest and a larch forest on the northern slope of Changbai Mountains, Northeast China. Chinese Journal of Applied Ecology, 25, 2149-2157. [匡旭, 邢丁亮, 张昭臣, 宋厚 娟, 王芸芸, 房帅, 原作强, 叶吉, 萄菲, 王绪高, 郝占 庆 (2014). 长白山北坡云冷杉林和落叶松林物种组成 与群落结构. 应用生态学报, 25, 2149-2157.]

Lei MD (1999). Vegetation of Shaanxi Province. Science Press, Beijing. [雷明德 (1999). 陕西植被. 科学出版社, 北 京.]

Li GL, Liu Y, Lü RH, Yu HQ, Li RS (2009). Responses of understory vegetation development to regulation of tree density in Larix principis-rupprechtii plantations. Journal of Beijing Forestry University, 31(1), 19-24. [李国雷, 刘 勇, 吕瑞恒, 于海群, 李瑞生 (2009). 华北落叶松人工 林密度调控对林下植被发育的作用过程. 北京林业大 学学报, 31(1), 19-24.]

Li N (1995). Studies on the geographic distribution, origin and dispersal of the Family Pinaceae Lindl. Acta Phytotaxonomica Sinica, 33, 105-130. [李楠 (1995). 论松科植物 的地理分布、起源和扩散. 植物分类学报, 33, 105-130.]

Li SH, Liang F, Guo JP (2012). Thinning effects on undercrown vegetation of Larix principis-rupprechtii plantation in Guandishan Mountain. Journal of Shanxi Agricultural University (Natural Science Edition), 32, 256-260. [李淑 辉, 梁芳, 郭晋平 (2012). 关帝山林区华北落叶松人工 林抚育间伐对林下植被的影响. 山西农业大学学报(自
然科学版), 32, 256-260.]

Liu HY, Tang ZY, Dai JH, Tang YX, Cui HT (2002). Larch timberline and its development in North China. Mountain Research and Development, 22, 359-367.

Liu L (1996). Vegetation of Hebei Province. Science Press, Beijing. [刘濂 (1996). 河北植被. 科学出版社, 北京.]

Liu XN (2001). The investigation on the impact of human activity on Larix chinensis. Shaanxi Forest Science and Technology, (3), 23-24. [刘香妮 (2001). 人为活动对太 白红杉林的影响调查. 陕西林业科技, (3), 23-24.]

Liu ZL, Fang JY, Piao SL (2002). Geographical distribution of species genera Abies, Picea and Larix in China. Acta Geographica Sinica, 57, 577-586. [刘增力, 方精云, 朴 世龙 (2002). 中国冷杉、云杉和落叶松属植物的地理分 布. 地理学报, 57, 577-586.]

Luo YJ, Zhang XQ, Wang XK, Zhu JH, Zhang ZJ, Sun GS, Gao F (2009). Biomass and its distribution patterns of Larix principis-rupprechtii plantations in northern China. Journal of Beijing Forestry University, 31(1), 13-18. [罗 云建, 张小全, 王效科, 朱建华, 张治军, 孙贵生, 高峰 (2009). 华北落叶松人工林生物量及其分配模式. 北京 林业大学学报, 31(1), 13-18.]

Ma FF, Zhang CM, Li YZ (2016). Density and distribution of organic carbon of Larix kaempferi plantation ecosystem in subtropics. Journal of Central South University of Forestry \& Technology, 36(1), 94-100. [马丰丰, 张灿明, 李 有志 (2016). 亚热带日本落叶松人工林生态系统碳密 度及其分配特征. 中南林业科技大学学报, 36(1), 94-100.]

Ma YP (2007). Study on Stand Structure of Larix kaempferi Forests and Its Increment Prediction-Taking Changlinggang Forest Farm as an Example. $\mathrm{PhD}$ dissertation, Beijing Forestry University, Beijing. 71-117. [马友平 (2007). 日本落叶松人工林林分结构与生长量预测研究 一以长岭岗林场为例. 博士学位论文, 北京林业大 学, 北京. 71-117.]

Mölder A, Streit M, Schmidt W (2014). When beech strikes back: How strict nature conservation reduces herb-layer diversity and productivity in Central European deciduous forests. Forest Ecology and Management, 319, 51-61.

Moles AT, Warton DI, Warman L, Swenson NG, Laffan SW, Zanne AE, Pitman A, Hemmings FA, Leishman MR (2009). Global patterns in plant height. Journal of Ecology, 97, 923-932.

Su YM (1995). Study on biomass and productivity of Larix kaempferi plantation. Journal of Sichuan Forestry Science and Technology, 16(3), 36-42. [宿以明 (1995). 日本落 叶松人工林生物量和生产力的研究. 四川林业科技, 16(3), 36-42.]

Tao SL, Guo QH, Li C, Wang ZH, Fang JY (2016). Global patterns and determinants of forest canopy height. Ecology, 97, 3265-3270. 
Tu YB (2008). Study on the Effect of Larix chinensis Forest Gap Characteristics on the Community Regeneration. Master degree dissertation, Shaanxi Normal University, Xi'an. 14-35. [涂云博 (2008). 太白红杉林林窗特征及 其对群落更新的影响研究. 硕士学位论文, 陕西师范大 学, 西安. 14-35.]

Tyrrell LE, Crow TR (1994). Structural characteristics of old-growth hemlock-hardwood forests in relation to age. Ecology, 75, 370-386.

Wang XP, Fang JY, Sanders NJ, White PS, Tang ZY (2009). Relative importance of climate vs local factors in shaping the regional patterns of forest plant richness across northeast China. Ecography, 32, 133-142.

Wang ZH, Rahbek C, Fang JY (2012). Effects of geographical extent on the determinants of woody plant diversity. Ecography, 35, 1160-1167.

Wu XJ, Chang JG, Yu JX, An Y, Guo JR (2010). Spatial distribution of Larix principis-rupprechtii-Picea spp. secondary forests along elevation gradients on north facing slope of Luya Mountain, Shanxi. Journal of Northeast Forestry University, 38(11), 10-14. [武秀娟, 常建国, 于 吉祥, 安雁, 郭建荣 (2010). 芦芽山阴坡华北落叶松云杉天然次生林群落特征的海拔梯度格局. 东北林业 大学学报, 38(11), 10-14.]

Wu ZY (1980). Vegetation of China. Science Press, Beijing. [吴征镒 (1980). 中国植被. 科学出版社, 北京.]

Xu LJ, Peng H, Chen CG (2005a). Size-class and age-class structures of Larix chinensis forests. Acta Botanica BorealiOccidentalia Sinica, 25, 460-465. [许林军, 彭鸿, 陈存 根 (2005a). 太白红杉林径级和龄级结构的研究. 西北 植物学报, 25, 460-465.]

Xu LJ, Peng H, Chen CG, Tang HL, Yang YJ (2005b). Quantitative analysis of the Larix chinensis forest's distribution at Qinling Mountains and the character of the alpine timberline at Taibai Mountain. Acta Botanica Boreali- Occidentalia Sinica, 25, 968-972. [许林军, 彭鸿, 陈存根, 唐 红亮, 杨亚娟 (2005b). 秦岭太白红杉林分布及太白山 高山林线特征的定量分析. 西北植物学报, 25 , 968-972.]

Yan GQ, Zhao GF, Hu ZH (2001). The study on Larix chinensis community characteristics and species diversity in Mts Qinling. Acta Botanica Boreali-Occidentalia Sinica, 21, 497-506. [阎桂琴, 赵桂仿, 胡正海 (2001). 秦岭太白
红杉群落特征及其物种多样性的研究. 西北植物学报, 21, 497-506.]

Yan HB, Han YZ, Yang XQ, Wang LY, Xiang XY (2010). Spatial distribution patterns and associations of tree species in typical natural secondary mountain forest communities of Northern China. Acta Ecologica Sinica, 30, 2311-2321. [间海冰, 韩有志, 杨秀清, 王丽艳, 项小英 (2010). 华北山地典型天然次生林群落的树种空间分布 格局及其关联性. 生态学报, 30, 2311-2321.]

Yan JH, Zhou GY, Zhang DQ, Tang XL, Wang X (2006). Different patterns of changes in the dry season diameter at breast height of dominant and evergreen tree species in a mature subtropical forest in South China. Journal of Integrative Plant Biology, 48, 906-913.

Ying JS, Chen ML (2011). Chinese Plant Geography. Shanghai Science and Technology Press, Shanghai. [应俊生, 陈梦 玲 (2011). 中国植物地理. 上海科学技术出版社, 上 海.]

Zhang JL, Zhou Y, Zhou GS, Xiao CW (2013). Structure and composition of natural gmelin larch (Larix gmelinii var. gmelinii) forests in response to spatial climatic changes. PLOS ONE, 8, e66668. DOI: 10.1371/journal.pone.0066668.

Zhang QD, Zhang JT, Zhang B, Cheng JJ, Tian SG, Suriguga (2010). Pattern of Larix principis-rupprechtii plantation and its environmental interpretation in Dongling Mountain. Journal of Wuhan Botanical Research, 28, 577-582. [张钦弟，张金屯，张斌，程佳佳，田世广，苏日古嘎 (2010). 东灵山华北落叶松人工林的分布格局及环境解 释. 武汉植物学研究, 28, 577-582.]

Zhao TS, Guang ZY, Zhao YM, Liu GW (1999). Study on biomass and productivity of Larix kaempferi plantation. Acta Agriculturae Universitatis Henanensis, 33, 350-353. [赵 体顺，光增云，赵义民，刘国伟 (1999). 日本落叶松人 工林生物量及生产力的研究. 河南农业大学学报, 33, 350-353.]

Zhao WZ (1997). Study on the artificial Larix principisrupprechtii forests in Bashang, Hebei Province. Journal of Desert Research, 17, 243-249. [赵文智 (1997). 河北坝 上半干旱/半湿润过渡带华北落叶松人工林研究. 中国 沙漠, 17, 243-249.]

特邀编委: 江 源 责任编辑: 李 敏 实习编辑: 赵 航 